\title{
Jasmonic acid elicits oxidative defense and detoxification systems in Cucumis melo L. cells
}

\section{Eetezaz Nafie*, Tahany Hathout, Al Shyma Al Mokadem}

Botany Department, University College of Women's for Art, Science and Education, Ain Shams University, Cairo, Egypt.

*Corresponding author: e-mail: oeetezaz@yahoo.com; Tel: +202-22736361

Received: 20 November 2010; Accepted: May 092011

\begin{abstract}
This study investigated whether a jasmonic acid (JA) elicitation strategy developed in a conventional cell suspension culture could evoke melon resistance mechanisms, including secondary metabolite production. Twenty one day cultured melon cell suspensions grown in MS1 medium were supplemented with JA at the concentrations of 0.5, 5.0 and $10 \mu \mathrm{mol}$. Melon cultures were sampled 24, 48 and $72 \mathrm{~h}$ post elicitation to evaluate different defense related factors such as antioxidant enzymes, ascorbate metabolism and phenolic compounds. Results suggest that melon cells respond to JA reprogramming the primary and secondary metabolism which will result in melon plantlets with enhanced resistance against diverse stress conditions through the production of specific bioactive molecules. Jasmonic acid elicited melon cells exhibited enhanced oxidative enzymes activities and ascorbic acid, coumarin and p-coumaric amounts were found without growth retardation. Induced intracellular JA functions as a signal transducer acting upstream to $\mathrm{H}_{2} \mathrm{O}_{2}$, which is a secondary messenger triggering jasmonic signaling cascades by activating certain late genes that regulate the activity of catalase, peroxidase and de novo synthesis of five isozymes, ascorbic peroxidase detoxifying enzymes concomitant with ascorbate compound. Secondary metabolite production in melon cells seems to be activated upon JA exposure suggesting that this cell culture could be used as a source for rapid and increased production of coumarin, p-coumaric, ascorbic acid and likely other specific phenylpropanoids. These data provides further evidences for a role of jasmonic acid in the intracellular signal cascade that results in the accumulation of secondary compounds and ultimately induced melon resistance. This approach could assist further in understanding the metabolic mechanisms operating in melon cells under stress, and thus how to control them.
\end{abstract}

Key words: ascorbic metabolism, detoxification enzymes, peroxidase isozymes, Phenolics profile.

\section{INTRODUCTION}

Melon (Cucumis melo L.) is an important vegetable crop that is widely cultivated in South East Asia, China, East Africa and throughout the tropical and subtropical regions (Yadav et al., 1996). The flesh fruit is a significant source of carbohydrates and water and the seeds are rich in oil and protein (Martyn and Miller, 1996). Melons are also considered an important source of ascorbic acid, folic acid, and potassium (Richter, 2000).
There are many potential sources of reactive oxygen species (ROS) formation in plants, some are reactions involved in normal metabolism, such as photosynthesis and respiration, other sources belong to pathways enhanced during biotic and abiotic stresses. In contrast to $\mathrm{O}_{2}$, ROS are capable of unrestricted oxidation of key cellular components and can lead to the oxidative destruction of the cell (Asada, 1999). Under normal growth conditions, the production of ROS in cells is low and tightly controlled; many stresses 
that disrupt the cellular homeostasis of cells enhance the production of ROS and induce specific oxidative responses. This enhanced production of ROS can pose a threat to cells but it is also thought that ROS act as signals for the activation of several stress-responses and defense pathways (Knight and Knight, 2001). Thus, ROS can be viewed as cellular indicators of stress as well as elicitors of stress-response signal transduction pathways.

Low molecular weight antioxidants, such as ascorbate, glutathione, and tocopherol, are information-rich redox buffers that interact with numerous cellular components. In addition to crucial roles in defense and as enzyme cofactors, these cellular antioxidants can also influence plant growth and development (Potters et al., 2004; Tokunaga et al., 2005). Notably, antioxidants provide essential information on cellular redox state, and they influence gene expression associated with biotic and abiotic stress responses to maximize the plant defense. Increasing evidence suggests a model for redox homeostasis in which the ROS-antioxidant interaction acts as a metabolic interface for signals derived from metabolism and from the environment. This interface modulates the appropriate induction of acclimation processes or, alternatively, execution of cell death programs. Further evidences point to a pivotal role for the ascorbicglutathione (AA-GSH) cycle that scavenges ROS, and particularly $\mathrm{H}_{2} \mathrm{O}_{2}$. Its activity relies on the sequential oxidation and re-reduction of $\mathrm{AA}$ and $\mathrm{GSH}$ in reactions catalyzed by the enzymes constituting the cycle, namely ascorbate peroxidase (APX), monodehydroascorbate reductase (MDHAR), dehydroascorbate reductase (DHAR), and glutathione reductase (GR) (Noctor and Foyer, 1998). In plant cells this cycle has been shown to operate in all organelles in which ROS detoxification is needed (Jimenez et al., 1997; Asada, 1999).

Apart from its function directly to detoxify ROS, the AA-GSH cycle is also involved in redox sensing and signaling (Pastori and Foyer, 2002). Hence, the specific interplay between ROS and the AA-GSH cycle constituents could generate compartment-specific changes in both the absolute concentrations of ROS and the antioxidant compounds, and in ascorbate and glutathione redox ratios. Under stress conditions these redox signals could interfere with signaling networks complementary to the antioxidant system and regulate defense gene expression (Vranova et al., 2002; Kiddle et al., 2003), thus coordinating the necessary readjustments in the redox-regulated plant defense to overcome the oxidative stress.

Although most of the AA is localized in the cytoplasm, certain amount is exported and localized in the apoplast (Noctor and Foyer, 1998). Apoplastic AA is thought to represent the first line of defense against potentially damaging external oxidants, and may play an important role in mediating response to stresses generating an enhanced oxidative burden (Barnes et al., 2002; Pignocchi and Foyer, 2003). In the apoplast, ascorbate oxidase oxidizes AA to the unstable radical monodehydroascorbate, which rapidly disproportionate to yield dehydroascorbate and AA (Smirnoff, 2000).

Jasmonic acid, and its derivatives are a family of important signal transducers, that can efficiently stimulate secondary metabolism in plant cells (Gundlach et al., 1992; Naill and Roberts, 2005; Wang et al., 2005). Since the first report regarding the effect of methyl jasmonate (MJ) on the accumulation of secondary metabolites in plant cell cultures (Gundlach et al., 1992), more than 100 plant species have been demonstrated to respond to the addition of MJ to the culture medium by accumulating secondary metabolites (Haider et al., 2000). Regarding the inducible mechanisms of jasmonates-stimulated secondary metabolite biosynthesis in plant cell cultures, to date, most efforts have been focused on the induction of plant defense responses including oxidative and nitric oxide bursts by the addition of jasmonates (Chong et al., 2005). But, in those studies, there was no information on the alteration of secondary metabolic gene expression. There is lack of reports on a causal link of signal cascade from defense signal response to gene activation and secondary metabolite accumulation in jasmonates-induced cell cultures. Therefore, it is worthwhile to assess the antioxidant enzymes activity, accumulation of phenolic acids and ascorbate in both, tissues and culture media to compare the differential responses between normal and elicited melon cells. The present paper aim to investigate if JA elicitation strategy developed in a conventional melon cell suspension culture could be used to evoke melon defense mechanisms and further, time secondary metabolite production. It is expected this approach provides future perspectives to cross-resistance process toward development of plants that respond and adapt faster to different environmental stresses. 


\section{MATERIAL AND METHODS}

This investigation was carried out from 2005 to 2009 at Gene Transfer Lab (GTL), and University College of Women's for Arts, Science and Education, Botany Department.

Material: Melon seeds (Cucumis melo L.) Egyptian cultivar Shahd El-Dokki was obtained from the Horticulture Research Institute, ARC,Giza, Egypt. Tissue culture chemicals: Hormones, jasmonic acid (JA) and other chemicals were purchased from Sigma and Fisher group.

\section{Biochemical and Molecular Responses of Jasmonic Acid}

Melon regeneration protocol: As previously described in (Nafie et al., 2009) three week-old-MS1 (MS medium supplemented with $\left(2 \mathrm{mg}^{-1} \mathrm{~L}\right.$ 2, 4-D; $0.1 \mathrm{mg}^{-1} \mathrm{~L} B A$ and 30 $\mathrm{g}^{-1} \mathrm{~L}$ sucrose) melon cell suspension culture was elicited by adding JA at different concentrations $(0.5,5$ and $10 \mu \mathrm{mol})$, melon cells were harvested after 24,48 , and 72 hours post elicitation. In the case of control cultures, $10 \mu \mathrm{L}$ of $70 \%$ ethanol was added to the three week-old-MS1 cell culture and cells were harvested at the same time intervals. Melon biochemical and molecular responses relevant to plant cell defense were assessed in JA-treated and control cells. The medium in which cells had been grown was also investigated by gradient elution high performance liquid chromatography (GC- HPLC).

Preparation of Extracts and Assay of Antioxidant Enzymes: For determination of antioxidant enzyme activities, lyophilized melon tissues $(0.5 \mathrm{~g})$ were homogenized in $10 \mathrm{~mL}$ of respective extraction buffer in a prechilled mortar and pestle under liquid nitrogen. The extract was immediately centrifuged at $19,000 \times \mathrm{g}$ for $20 \mathrm{~min}$ at $20^{\circ} \mathrm{C}$. The supernatant was then used immediately for measuring the following enzymes activities.

Catalase enzyme extraction and enzyme activity assay: Catalase (EC 1.11.1.6) was extracted following Jiang and Zhang (2002) method in which $10 \mathrm{~mL}$ of 50 mmol potassium phosphate buffer ( $\mathrm{pH} 7.0$ ) containing 1 mmol ethylene diamine tetra acetic acid (EDTA) and 1\% polyvinylpyrrolidone (PVP) was the extraction media. After filtration and centrifugation, the supernatant was used as crude enzyme extract. Catalase activity was estimated following Aebi (1984) protocol in which the reaction mixture was: 50 mmol potassium phosphate buffer (pH 7.0), 10 mmol $\mathrm{H}_{2} \mathrm{O}_{2}$ and $200 \mu \mathrm{L}$ of enzyme extract in a final $3 \mathrm{~mL}$ volume. Reaction was left for $10 \mathrm{~min}$ then stopped by adding $1 \mathrm{~mL}$ of $1 \mathrm{~mol} \mathrm{HCl}$ as reported by Yingsanga et al. (2008). Catalase activity was estimated spectrophotometrically (JENWAY 6305 UV/VIS) at $240 \mathrm{~nm}$, expressed as mmol $\mathrm{H}_{2} \mathrm{O}_{2}$ decomposed $\mathrm{min}^{-1} \mathrm{~g}^{-1} \mathrm{FW}$.

Soluble and cell wall-bound peroxidase enzymes extraction and activity assay: Soluble and cell wall-bound peroxidase (POD) (EC 1.11.1.7) was extracted following Jiang et al. (1984). Lyophilized melon tissues $(0.5 \mathrm{~g})$ were homogenized in cold extraction buffer containing $10 \mathrm{~mL}$ of $100 \mathrm{mmol}$ sodium phosphate buffer $(\mathrm{pH} 7.0)$ and 0.5 g polyvinyl polypyrrolidone (PVPP). After centrifugation, supernatant was considered crude enzyme. Cell-wall bound was extracted by washing pellet twice with same previous phosphate buffer, twice with water and, then shacked in $2 \%$ Triton $\mathrm{X}-100$ for $1 \mathrm{~h}$ at $4{ }^{\circ} \mathrm{C}$, then again rinsed five times with water. Pellet after that was treated with $1 \mathrm{~mol} \mathrm{CaCl}_{2}$ with gentle shaking for $12 \mathrm{~h}$. After centrifugation, the supernatant was used for cell wall-bound POD activity assay. Peroxidase activity was measured following Ranieri et al. (1995) method .Reaction mixture consisting of $50 \mu \mathrm{L}$ enzyme extract, 20 mmol guaiacol and $100 \mathrm{mmol}$ sodium phosphate buffer, $\mathrm{pH}$ 7.0 in $3 \mathrm{~mL}$, total volume. Reaction was initiated by $20 \mu \mathrm{L}$ $\mathrm{H}_{2} \mathrm{O}_{2}$ addition and terminated after $10 \mathrm{~min}$ by adding $1 \mathrm{~mL}$ of $1 \mathrm{~mol} \mathrm{HCl}$ as reported by Yingsanga et al. (2008). POD activity was determined by measuring the increase in absorbance at $470 \mathrm{~nm}$ and expressed as $\Delta \mathrm{min}^{-1} \mathrm{gm}^{-1}$.

\section{Peroxidase isozyme analysis}

Isozymes extraction: Peroxidase isozymes were extracted from lyophilized samples by homogenizing tissues sampled from different treatments in extraction buffer contains: $150 \mathrm{mmol}$ Tris $\mathrm{HCl}(\mathrm{pH} \mathrm{6.8)}$ and $30 \%$ glycerol. The extract was then transferred into clean Eppendorf tubes and centrifuged at $10000 \mathrm{rpm}$ for $5 \mathrm{~min}$. Then supernatant was transferred to new clean Eppendorf tubes and kept at $-20^{\circ} \mathrm{C}$. Peroxidase isozyme assay native polyacrylamide gel electrophoresis (PAGE) was done similar to Yamunarani et al. (2004) protocol. 
Gel preparation and sample application: Separating gel $12 \%$ was prepared by mixing $3.3 \mathrm{~mL} \mathrm{H}_{2} \mathrm{O}, 4 \mathrm{~mL}$ of $30 \%$ acrylamide, $2.5 \mathrm{~mL}$ of $1.5 \mathrm{~mol}$ Tris $\mathrm{HCl} \mathrm{pH}$ (8.8), $100 \mu \mathrm{L}(10 \%)$ ammonium persulfate and $4 \mu \mathrm{L}, \mathrm{N}, \mathrm{N}, \mathrm{N}, \mathrm{N}$ -Tetramethylethylene diamine (TEMED). Stacking gel 5\% was prepared by mixing $3.4 \mathrm{~mL} \mathrm{H}_{2} \mathrm{O}, 0.83 \mathrm{~mL}$ of $30 \%$ acrylamide, $0.63 \mathrm{~mL}$ of $0.5 \mathrm{~mol}$ Tris $\mathrm{HCl} \mathrm{pH}(6.8), 50 \mu \mathrm{L}$ ammonium persulfate (10\%) and $10 \mu \mathrm{L}$ TEMED and then poured over the separating gel. A volume of $40 \mu \mathrm{L}$ extract from each sample was mixed with $10 \mu \mathrm{L}$ bromophenol blue, and then $40 \mu \mathrm{L}$ from this mixture was applied to each well. The run electrode buffer $(0.1 \mathrm{~mol}$ potassium phosphate buffer, pH 5.0) was added to both lower and upper tanks. The apparatus was connected to the power supply. Electrophoresis apparatus was attached to circulating cool system during running which last 3-4 $\mathrm{h}$.

Isozyme assay: Peroxidase (POD) isoforms were then visualized by incubating the gel under dark condition in freshly prepared diaminobenzidine solution (10 mg in $20 \mathrm{~mL} 0.05 \mathrm{~mol}$ phosphate buffer, pH 5.0) for 5-10 min, then the gel washed twice with water and incubated carefully with $10 \mu \mathrm{L}$ of $30 \%$ $\mathrm{H}_{2} \mathrm{O}_{2}$ in $20 \mathrm{~mL}$ of the $0.05 \mathrm{~mol}$ phosphate buffer, pH 5.0 until the POD activity-containing brown bands visualized.

Polyphenol oxidase enzyme extraction and activity assay: Lyophilized cells were homogenized in cold extraction buffer of $100 \mathrm{mmol}$ sodium phosphate buffer $\mathrm{pH}$ (7.0) and $0.5 \mathrm{~g}$ PVPP for polyphenol oxidase (PPO)(EC 1.10.3.1) for extraction as described by Luh and Phithakpol (1972). The homogenate was filtered then centrifuged and the supernatant was considered the crude enzyme extract. Enzyme activity in the supernatant fraction was determined at $25^{\circ} \mathrm{C}$ within $6 \mathrm{~h}$ after preparation. For the PPO enzyme assay, $1 \mathrm{ml}$ of supernatant was mixed with $1 \mathrm{~mL}$ of sodium phosphate buffer (100 mmol, pH 7.0) and $1 \mathrm{~mL}$ catechol $50 \mathrm{mmol}$. Reaction was terminated after $10 \mathrm{~min}$ as reported by Yingsanga et al. (2008). Activity was measured and expressed as $\Delta A_{410}$ $\mathrm{min}^{-1} \mathrm{~g}^{-1} \mathrm{FW}$.

Phenylalanine ammonia-lyase extraction and activity assay: Melon cells were homogenized in extraction buffer contains $0.1 \mathrm{~mol}$ borate buffer, $\mathrm{pH} 7.0$ and $0.1 \mathrm{~g}$ PVP. The homogenate after filtration and centrifugation was collected and used for enzyme assay. Phenylalanine ammonia-lyase (PAL) (EC 4.3.1.24) activity was determined spectrophotometrically by assaying the rate of conversion of L-phenylalanine to trans- cinnamic acid at $290 \mathrm{~nm}$, as described by Dickerson et al. (1984). Reaction mixtures consisted of $0.4 \mathrm{~mL}$ of enzyme extract, $0.5 \mathrm{~mL}$ of $0.1 \mathrm{~mol}$ borate buffer $\mathrm{pH} 8.8$ and $0.5 \mathrm{~mL}$ of $12 \mathrm{mmol}$ phenylalanine in the same buffer. The reaction mixtures were incubated for $15 \mathrm{~min}$ at $30^{\circ} \mathrm{C}$ in a water bath and reaction was terminated and stopped as described by Yingsanga et al. (2008). In reference cell, $0.4 \mathrm{~mL}$ of enzyme extract was taken along with $1.0 \mathrm{~mL}$ borate buffer. The amount of trans-cinnamic acid synthesized was calculated using a calibrated sample. Enzyme activity was expressed $\mu \mathrm{mol}$ trans-cinnamic min $^{-1} \mathrm{~g}^{-1} \mathrm{FW}$.

Ascorbate oxidase extraction and activity assay: Ascorbate oxidase (AO) (EC 1.10.3.3) enzyme extraction was done following Oberbacher and Vines (1963) method. Lyophilized melon cells were ground in extraction buffer ( 0.1 mol potassium phosphate, $\mathrm{pH} \mathrm{7.0)}$ on ice, then filtered to discard any remaining tissues, homogenate was centrifuged and the supernatant was used as crude enzyme extract.

Enzyme activity assay was determined according to Esaka et al. (1988). The reaction mixture contained $20 \mathrm{mmol}$ K-phosphate buffer (pH 7.5) and $2.5 \mathrm{mmol}$ ascorbic acid. The reaction was initiated with the addition of enzyme extract and left for 10 min then terminated as described by Yingsanga et al. (2008). Enzyme activity was measured by the decrease in absorbance at $265 \mathrm{~nm}$ due to ascorbate oxidation and expressed as mmol oxidized ascorbate $\mathrm{min}^{-1} \mathrm{~g}^{-1} \mathrm{DW}$.

Ascorbate peroxidase extraction and activity assay: Soluble proteins were extracted by homogenizing the lyophilized cell tissues in $10 \mathrm{~mL}$ of $50 \mathrm{mmol}$ potassium phosphate buffer (pH 7.0) containing $1 \mathrm{mmol}$ EDTA and 1\% polyvinylpyrrolidone (PVP) with the addition of $1 \mathrm{mmol}$ ascorbic acid (ASC). The homogenate was filtered and centrifuged, and then the supernatant was used for enzyme assay (Jiang and Zhang, 2002). Ascorbate peroxidase (EC 1.11.1.11) activity was measured by monitoring the decrease in absorbance at $290 \mathrm{~nm}$. The assay reaction mixture contained $50 \mathrm{mmol}$ potassium phosphate buffer ( $\mathrm{pH} 7.0$ ), $0.5 \mathrm{mmol}$ ascorbic acid, $0.1 \mathrm{mmol}$ hydrogen peroxide, and $200 \mu \mathrm{L}$ of enzyme extract. The reaction was initiated by adding enzyme extract (Nakano and Asada, 1981) and left for 10 min then terminated as described by Yingsanga et al. (2008). Enzyme activity was expressed as mmol oxidized ascorbate $\mathrm{min}^{-1} \mathrm{~g}^{-1} \mathrm{FW}$. 
Glutathione reductase extraction and enzyme activity assay: Glutathione reductase (GR) (EC 1.8.1.10) was extracted according to (Hodges et al., 1997) method with some modification. Lyophilized tissues were ground in extraction buffer contains $50 \mathrm{mmol}$ phosphate buffer $(\mathrm{pH} 7$ containing $0.1 \mathrm{mmol}$ EDTA and $1 \%$ PVP) in pre chilled mortar and pestle, after filtration and centrifugation the supernatant was used as crude enzyme extract. Glutathione reductase activity was monitored at $340 \mathrm{~nm}$ in $1 \mathrm{~mL}$ reaction mixture containing $50 \mathrm{mmol}$ potassium phosphate buffer (pH 7.8), $15 \mathrm{mmol}$ ethylenediaminetetraacetic acid, $5 \mathrm{mmol}$ oxidized glutathione (GSSG), $1.5 \mathrm{mmol}$ NADPH and enzyme extract. The reaction was initiated by adding NADPH lifted for 5 min and then reaction was terminated as described by Yingsanga et al. (2008). Enzyme activity was expressed as mmol oxidized NADPH min $^{-1} \mathrm{~g}^{-1} \mathrm{DW}$.

\section{Extraction and Quantificational of Secondary Metabolites}

Phenolics profile analysis in melon cells and its culture media: Melon cell suspensions were comminuted with a mortar and pestle in the presence of liquid nitrogen. Freezed $1 \mathrm{~g}$ tissue sample was suspended in $5 \mathrm{~mL}$ of ethanol 95\% (v/v), homogenized for $3 \mathrm{~min}$, and then incubated at $48^{\circ} \mathrm{C}$ for $1 \mathrm{~h}$. Samples, from cell suspensions were then prepared for HPLC analysis as detailed by Buschmann et al. (2000). While cell suspension media was directly injected to the HPLC, chlorophyll was removed from $200 \mu \mathrm{L}$ samples in methanol by addition of $200 \mu \mathrm{L}$ of water at $0^{\circ} \mathrm{C}$; chlorophyll precipitated after about $4 \mathrm{~h}$, samples were centrifuged ( $2 \mathrm{~min}$, $4^{\circ} \mathrm{C}, 10000 \mathrm{~g}$ ), filtered through micro filter $0.45 \mu \mathrm{mol}$ and injected. Phenolic compound analysis was performed on HPLC model (HP1050) equipped with UV detector. Phenolics were identified by their retention times, as detailed by Buschmann et al. (2000). Quantification was based on reference compounds as external standards; standards were obtained from Sigma.

Total flavonoids: Total flavonoids was extracted from lyophilized melon tissue $(0.1 \mathrm{~g})$ by homogenizing in $4 \mathrm{~mL}$ of ethanol: acetone $7: 3$, (v/v) for $1 \mathrm{~h}$ at $37^{\circ} \mathrm{C}$ according to Lee and Wicker (1991). Residue was re extracted using same conditions. The two filtrates were combined and then stored at $-20^{\circ} \mathrm{C}$ until needed for assay. Total flavonoids content was determined following Yong et al. (2008). In a $10 \mathrm{~mL}$ Eppendorf tube, $0.3 \mathrm{~mL}$ melon extract, $3.4 \mathrm{~mL} 30 \%$ ethanol, and 0.15 $\mathrm{mL}$ of $0.3 \mathrm{~mol} \mathrm{~L}^{-1} \mathrm{AlCl}_{3} \cdot 6 \mathrm{H}_{2} \mathrm{O}$ were added and mixed. After $5 \mathrm{~min}, 1 \mathrm{~mL}$ of $1 \mathrm{~mol} \mathrm{~L}^{-1} \mathrm{NaOH}$ was added, and the mixture was measured at $506 \mathrm{~nm}$. Total flavonoids concentration was calculated from a calibrated sample using querctein and expressed as $\mu$ g querctein $\mathrm{g}^{-1} \mathrm{DW}$.

Ascorbic acid content in melon cells and culture media: Intracellular ascorbic acid (AA) was measured as described by Jagota and Dani (1982) in which $0.1 \mathrm{~g}$ lyophilized tissue sample was homogenized in $1.5 \mathrm{~mL} 10 \%(\mathrm{w} / \mathrm{v})$ trichloroacetic acid (TCA) at $4^{\circ} \mathrm{C}$ and centrifuged at $3000 \mathrm{~g}$ for $5 \mathrm{~min}, 0.3 \mathrm{~mL}$ of the supernatant was made up to $2 \mathrm{~mL}$ volume with distilled water. Extracellular AA was estimated in culture media. 0.2 $\mathrm{mL}$ 10\% (v/v) Folin phenol reagent (Sigma Chemical, Egypt) was then added to the mixture, and vigorously shaken. After 10 min reaction time, maximum absorbance was measured at $760 \mathrm{~nm}$, a result of the reaction between ascorbic acid and Folin phenol reagent. $L(+)$-ascorbic acid (Sigma, Egypt) was used as a standard. The intra and extracellular ascorbate content was calculated from the prepared standard curve and expressed as $\mathrm{mg} \mathrm{g}^{-1} \mathrm{DW}$ and $\mu \mathrm{g} \mathrm{mL}^{-1}$. For the preparation of standard curve , ascorbic acid solutions, $1000-50 \mu \mathrm{g} \mathrm{mL}^{-1}$ serial solutions were prepared. For the colorimetric assay Folin phenol reagent was used, maximum absorbance was measured at $760 \mathrm{~nm}$.

Statistical analysis: Experiments were set up with three replicates. The data were subjected to one-way analysis of variance (ANOVA) and means were compared using the least significant difference (LSD) at the $5 \%$ probability level, standard deviation (SD) was calculated and represented in the figures.

\section{RESULTS}

Changes in Activities of Antioxidant Enzymes of the Melon Cell Suspension: Figure1 show that activities of catalase enzyme in melon cells, increased under jasmonic acid (JA, 0.5, 5 and $10 \mu \mathrm{mol})$ elicitation at different exposure periods in respect to control. After $72 \mathrm{~h}$ elicitation JA at 0.5 and $5 \mu \mathrm{mol}$ concentrations induced average $0.9-1.2 \%$ increases respectively, while $10 \mu \mathrm{mol} \mathrm{JA}$-elicited melon cells induced highly significant increase reaching about $24 \%$. 


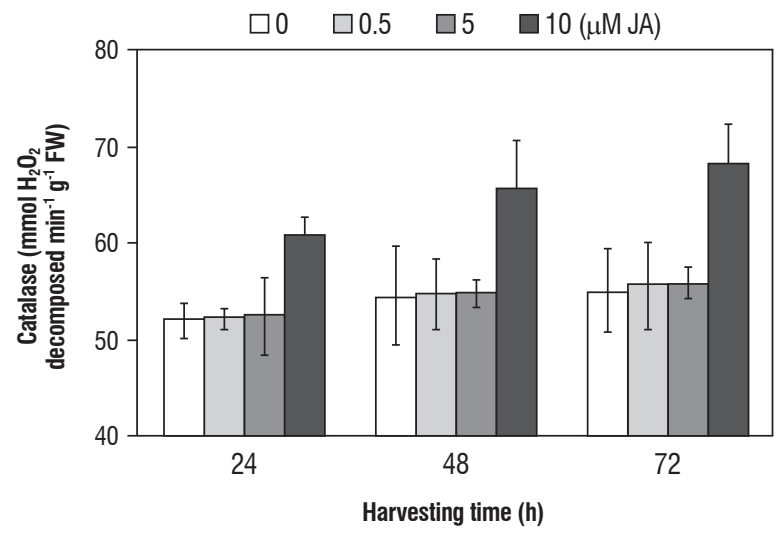

Figure 1. Changes in the catalase activity in suspension-cultured melon cells 24 , 48 and $72 \mathrm{~h}$ harvested post JA-elicitation. The data are mean values $\pm S D(n=3)$.

Soluble peroxidase enzyme activity increased in response to exogenous JA application, compared to control as illustrated in Figure2a. Elicited melon cells using $0.5-10$ $\mu \mathrm{mol} \mathrm{JA}$ and harvested 24 and $72 \mathrm{~h}$ post elicitation, induced a statistically significant $(P<0.05)$ average $(3.2,21$ and $43 \%)$ and $(3.5,52.6$ and $83.5 \%)$ increase, respectively.

Melon cells under the influence of external jasmonic application, respond by increment in the cell wall-bound peroxidase activity over the control. Data was represented in (Figure2b).

Results demonstrate that melon cells activated this enzyme after $24 \mathrm{~h}$ in the presence of $0.5-10 \mu \mathrm{mol} \mathrm{JA}$ to approximately 17.6, 29.2 and $137 \%$ respectively. The enzyme reached its maximum activity after $48 \mathrm{~h}$ after exposure to $\mathrm{JA}$ and then dropped after $72 \mathrm{~h}$ but to levels still higher than that estimated after the $24 \mathrm{~h}$ levels. The highest estimated activity was induced by $10 \mu \mathrm{mol} \mathrm{JA}$ reaching $139 \%$ over the control after two days exposure. In melon cells, peroxidase enzyme exhibit as multiple isoforms and the spectrophotometer analysis indicate only the combined activity of different isoforms. Therefore, we analyzed the isoform composition of peroxidase enzyme by native polyacrylamide gel electrophoresis (native-PAGE). Alterations in isoform profile of melon cell culture peroxidases resulted from applying JA were examined by discontinuous native-PAGE results were illustrated in (Figure2c).

Scanning the native stained gel for the enzyme activity revealed the presence of five peroxidase isoforms namely $(A, B$, $\mathrm{C}, \mathrm{D}$ and $\mathrm{E}$ ) detected in melon cells extract. The yielded isoform named $(A)$ was a single sharp protein band, intensively observed in elicited cells and was JA dependent, compared to low intensive band in non elicited cells. Band (B) was induced by $10 \mu \mathrm{mol} J \mathrm{~A}$ as a de novo synthesized isoform. The other two isoforms (C, D) were sharper in melon cells elicited by $5 \mu \mathrm{mol} J \mathrm{~J}$ after $48 \mathrm{~h}$ than all other treatments including the control. Finally, the isoform named $(\mathrm{E})$ was de novo synthesized in cells treated with $(5,10$ $\mu \mathrm{mol} \mathrm{JA}$ ) throughout the experiment period and disappeared from the lower jasmonic dose and the non elicited control as if it needs certain JA concentration to be expressed.
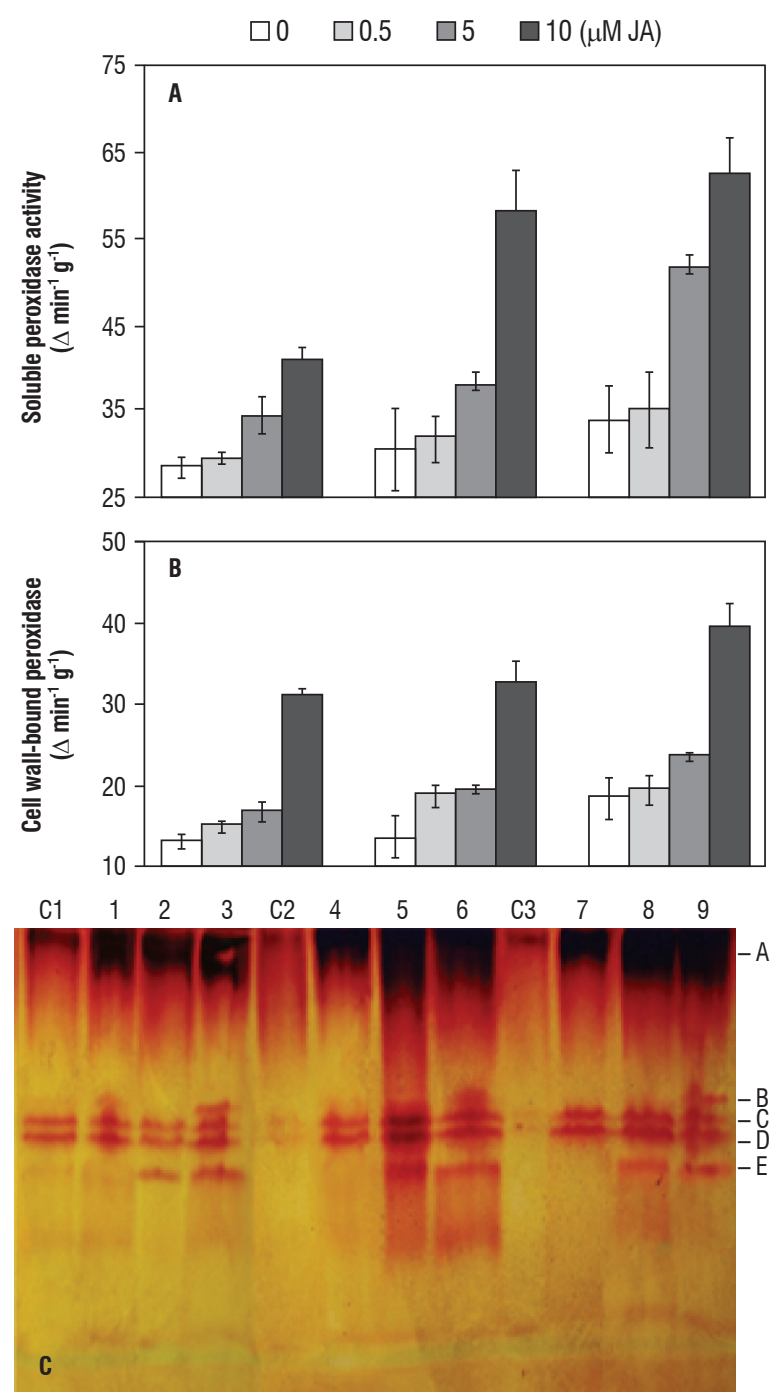

Figure 2. Effect of jasmonic acid (JA) on the soluble (A) and cell wall-bound (B) activities during different harvesting times for the melon cell suspension culture cultivated in MS1 medium. The data are mean values $\pm S D(n=3)$. Peroxidase isoforms revealed in a $12 \%$ native PAGE on the day 21 st upon JA treatment. Lane C1: from calli untreated harvested $24 \mathrm{~h}$, lane 1: from calli treated with 0.5 $\mu$ mol JA harvested 24h, Lane 2: $5 \mu \mathrm{mol}$ JA harvested 24h, Lane 3: $10 \mu \mathrm{mol}$ JA harvested 24h, Lane C2: from calli untreated harvested 48h, Lane 4: from calli treated with $0.5 \mu \mathrm{mol}$ JA harvested 48h, Lane $5: 5 \mu \mathrm{mol}$ JA harvested 48h, Lane 6: $10 \mu \mathrm{mol}$ JA harvested 48h, Lane C3: from calli untreated harvested 72h,Lane 7: from calli treated with $0.5 \mu \mathrm{mol}$ JA harvested 72h, Lane 8: $5 \mu \mathrm{mol}$ JA harvested 72h, Lane 9: $10 \mu \mathrm{mol}$ JA harvested 72h. Symbols (A, B, C, D, E) indicate de novo peroxidase isoforms in JA treated calli. (C). 
Alterations in Ascorbic Acid Metabolism in the Melon Cell Suspension: To investigate the ascorbic acid (AA) metabolism under the influence of $0.5,5$ and $10 \mu \mathrm{mol} \mathrm{JA}$, alterations in $\mathrm{AA}$ in the medium and in the cells, the activity of three related enzymes ascorbic peroxidase (AP0), ascorbic oxidase (AO) and glutathione reductase (GR) compared to the control after experiment different time points. Data were represented analyzed statistically and recorded in Tables 1-4.

Table 1. Effect of jasmonic acid (JA) application on the intra - and extracellular ascorbic acid content in melon cell suspension culture cultivated in MS1 medium.

\begin{tabular}{|c|c|c|c|c|c|c|}
\hline \multirow{2}{*}{$\begin{array}{c}\mathrm{JA} \\
(\mu \mathrm{mol})\end{array}$} & \multicolumn{3}{|c|}{$\begin{array}{l}\text { Intracellular ascorbic acid } \\
\text { (mg/g D w) }\end{array}$} & \multicolumn{3}{|c|}{ Extracellular ascorbic acid $(\mu \mathrm{g} / \mathrm{mL})$} \\
\hline & $24 \mathrm{~h}$ & $48 \mathrm{~h}$ & $72 \mathrm{~h}$ & $24 \mathrm{~h}$ & $48 \mathrm{~h}$ & $72 \mathrm{~h}$ \\
\hline Control & $11.90 \pm 0.37 b$ & $12.50 \pm 0.64 c$ & $13.00 \pm 0.55 c$ & $40.00 \pm 1.24 c$ & $45.00 \pm 2.30 \mathrm{ab}$ & $46.00 \pm 1.93 \mathrm{a}$ \\
\hline 0.5 & $11.00 \pm 0.83 b$ & $10.50 \pm 0.26 d$ & $13.00 \pm 0.36 c$ & $31.50 \pm 2.36 \mathrm{~d}$ & $30.00 \pm 0.75 c$ & $40.00 \pm 1.12 b$ \\
\hline 5 & $15.85 \pm 0.33 a$ & $16.00 \pm 1.07 b$ & $15.75 \pm 1.28 b$ & $47.50 \pm 1.00 \mathrm{~b}$ & $44.00 \pm 2.95 b$ & $35.00 \pm 2.84 \mathrm{c}$ \\
\hline 10 & $16.75 \pm 1.06 \mathrm{a}$ & $19.00 \pm 1.46 \mathrm{a}$ & $23.50 \pm 0.63 a$ & $52.50 \pm 1.42 \mathrm{a}$ & $50.00 \pm 3.85 a$ & $34.00 \pm 2.14 \mathrm{c}$ \\
\hline LSD at $5 \%$ & 1.083 & 1.824 & 1.683 & 2.995 & 5.101 & 3.949 \\
\hline
\end{tabular}

Values (means of three replicates \pm SD) in the same column followed by the same letter are not significantly different at $p<0.05$.

Table 2. Effect of jasmonic acid $(\mathrm{JA})$ on ascorbate peroxidase enzyme activity during different harvesting times in the melon cell suspension culture cultivated in MS1 medium.

\begin{tabular}{cccc}
\hline \multirow{2}{*}{$\begin{array}{c}\text { JA } \\
\mu \mathrm{mol})\end{array}$} & \multicolumn{3}{c}{$\begin{array}{c}\text { Ascorbate peroxidase activity } \\
\left(\mathrm{m} \mathrm{mol} \text { oxidized ascorbate } \mathrm{min}^{-1} \mathrm{gm}^{-1} \mathrm{fw}\right)\end{array}$} \\
\cline { 2 - 4 } & $24 \mathrm{~h}$ & $48 \mathrm{~h}$ & $72 \mathrm{~h}$ \\
\hline Control & $0.87 \pm 0.03 \mathrm{~d}$ & $0.88 \pm 0.04 \mathrm{c}$ & $0.91 \pm 0.04 \mathrm{c}$ \\
0.5 & $1.00 \pm 0.08 \mathrm{c}$ & $1.25 \pm 0.02 \mathrm{~b}$ & $1.5 \pm 0.03 \mathrm{~b}$ \\
5.0 & $1.20 \pm 0.03 \mathrm{~b}$ & $1.27 \pm 0.09 \mathrm{~b}$ & $1.6 \pm 0.09 \mathrm{~b}$ \\
10.0 & $1.30 \pm 0.04 \mathrm{a}$ & $1.5 \pm 0.10 \mathrm{a}$ & $1.8 \pm 0.07 \mathrm{a}$ \\
LSD at $5 \%$ & 0.090 & 0.134 & 0.117 \\
\hline
\end{tabular}

Values (means of three replicates \pm SD) in the same column followed by the same letter are not significantly different at $p<0.05$.

Table 3. Effect of jasmonic acid (JA) on ascorbate oxidase enzyme activity during different harvesting times in the melon cell suspension culture cultivated in MS1 medium.

\begin{tabular}{cccc}
\hline \multirow{2}{*}{$\begin{array}{c}\text { JA } \\
(\mu \mathrm{mol})\end{array}$} & \multicolumn{3}{c}{ Ascorbate oxidase activity } \\
\cline { 2 - 4 }$\left(\mathrm{m} \mathrm{mol}\right.$ oxidized ascorbate $\left.\mathrm{min}^{-1} \mathrm{~g}^{-1} \mathrm{DW}\right)$ \\
\hline Control & $0.88 \pm 0.03 \mathrm{~b}$ & $0.39 \pm 0.02 \mathrm{c}$ & $0.82 \pm 0.03 \mathrm{~b}$ \\
0.5 & $0.71 \pm 0.05 \mathrm{c}$ & $0.39 \pm 0.01 \mathrm{c}$ & $0.41 \pm 0.01 \mathrm{c}$ \\
5.0 & $0.91 \pm 0.02 \mathrm{~b}$ & $0.82 \pm 0.06 \mathrm{~b}$ & $0.76 \pm 0.06 \mathrm{~b}$ \\
10.0 & $2.71+0.07 \mathrm{a}$ & $2.70 \pm 0.21 \mathrm{a}$ & $1.47 \pm 0.09 \mathrm{~s}$ \\
LSD at $5 \%$ & 0.088 & 0.205 & 0.107 \\
\hline
\end{tabular}

Values (means of three replicates \pm SD) in the same column followed by the same letter are not significantly different at $p<0.05$.
Table 4. Effect of jasmonic acid (JA) on glutathione reductase enzyme activity during different harvesting times in the melon cell suspension culture cultivated in MS1 medium.

\begin{tabular}{cccc}
\hline \multirow{2}{*}{$\begin{array}{c}\mathrm{JA} \\
\mu \mathrm{mol})\end{array}$} & \multicolumn{3}{c}{$\begin{array}{c}\text { Glutathione reductase activity } \\
\left(\mathrm{m} \mathrm{mol} \text { oxidized NADPH } \text { min }^{-1} \mathrm{~g}^{-1} \mathrm{DW}\right)\end{array}$} \\
\cline { 2 - 4 } & $24 \mathrm{~h}$ & $48 \mathrm{~h}$ & $72 \mathrm{~h}$ \\
\hline Control & $15.80 \pm 0.49 \mathrm{c}$ & $16.0 \pm 0.85 \mathrm{a}$ & $16.00 \pm 0.67 \mathrm{a}$ \\
0.5 & $19.10 \pm 1.43 \mathrm{~b}$ & $20.5 \pm 0.34 \mathrm{~b}$ & $22.5 \pm 0.34 \mathrm{~b}$ \\
5.0 & $20.66 \pm 0.43 \mathrm{ab}$ & $22.8 \pm 1.13 \mathrm{a}$ & $24.5 \pm 1.37 \mathrm{a}$ \\
10.0 & $20.90 \pm 0.56 \mathrm{a}$ & $25.9 \pm 1.33 \mathrm{a}$ & $28.8 \pm 0.87 \mathrm{~b}$ \\
LSD at $5 \%$ & 1.571 & 1.854 & 1.684 \\
\hline
\end{tabular}

Values (means of three replicates \pm SD) in the same column followed by the same letter are not significantly different at $p<0.05$.

During time-course experiments the AA content in intracellular and extracellular control cells showed slow increment in parallel to the cells growth. Melon callus exposed to $0.5 \mu \mathrm{mol} \mathrm{JA}$ triggered significant negative changes in the AA contents estimated in melon tissue and in its growth medium through the tested time. Compared to the control the highest decrease was $16 \%$ and $33 \%$ in intracellular and extracellular AA after $48 \mathrm{~h}$ respectively. Melon tissue treated with $5 \mu \mathrm{mol} \mathrm{JA}$ exhibited a significant increase reached peak (33\%) after $24 \mathrm{~h}$ and continued to decline reached $21 \%$ over the control. Mean while the melon tissue treated with $10 \mu \mathrm{mol}$ JA showed time dependent accumulation reached its peak $(80.7 \%)$ over the control after three days (72 h) elicitation. On 
the other hand, estimated AA at elicited growth medium with 5 or $10 \mu \mathrm{mol} \mathrm{JA}$ was significantly higher than its control after 24 h. In contrast after $72 \mathrm{~h}$ estimated AA was lower in all elicited growth media, the highest decrease was in the $10 \mu \mathrm{mol} J \mathrm{~J}$ growth medium (26\% lower than the control).

Ascorbate peroxidase (APX) share crucially in the detoxification of $\mathrm{H}_{2} \mathrm{O}_{2}$, according to the following reaction:

$$
2 \text { ascorbate }+\mathrm{H}_{2} \mathrm{O}_{2} \rightarrow 2 \text { monodehydroascorbate }+2 \mathrm{H}_{2} \mathrm{O}
$$

Effect of exogenous application of JA as chemical elicitor on the activity of ascorbate peroxidase enzyme in melon cell suspension culture was studied (Table2). The enzyme activity enhancement was JA dose and harvesting time depended with respect to the control. Jasmonic acid at 0.5 $\mu \mathrm{mol}$ concentration induced a statistically significant average $14.9,42$ and $64.8 \%$ increase at interval harvesting times, respectively. Moreover, JA at $10 \mu \mathrm{mol}$ induced statistically highly significant average 49.4, 70.5 and $97.8 \%$ increase respective to interval harvesting times.

The effect of extracellular addition of JA as chemical elicitor in melon cell suspension culture on the activity of ascorbate oxidase $\mathrm{AO}$ enzyme was also studied. The data was tabulated in Table3. As shown in Table 3, JA at $10 \mu \mathrm{mol}$ concentrations induced highly significant average 207.9, 592.3 and $79.2 \%$ increase respective to interval harvesting time. In contrast JA at 0.5 and $5 \mu \mathrm{mol}$ concentrations induced significant average 50, 7.3\% lower than the control respectively at $72 \mathrm{~h}$ harvesting time.

We further examined the effect of JA on glutathione reductase enzyme activity in melon cell suspension. Under the influence of $0.5,5$, and $10 \mu \mathrm{mol} \mathrm{JA}$, changes in the antioxidant enzyme GR compared to the control non elicited was recorded. The data was statistically analyzed and illustrated in Table 4.

The GR enzyme activity in melon cells was activated in dose and time dependent manner with respect to the control. Jasmonic acid at $0.5 \mu \mathrm{mol}$ concentration induced a statistically significant average 20.8, 28.1 and $40.6 \%$ increase respective to interval harvesting time. Moreover the $10 \mu \mathrm{mol} \mathrm{JA}$ concentration induced the highest average 32.2, 61 and $80 \%$ increases during $24-48$ and $72 \mathrm{~h}$ post elicitation compared to the control.
Alterations in Phenolic Compound Metabolism in Melon Cell Suspension Culture: The effect of JA on the secondary compound induction and two related enzymes phenylalanine ammonia-lyase (PAL) and polyphenol oxidase (PPO) were examined in melon cell suspension to evaluate its response after exogenous JA application.

The effect of exogenous JA application on PAL activity was analyzes in melon cell suspension to assess its response. Under the influence of $0.5,5$ and $10 \mu \mathrm{mol} \mathrm{JA}$ an increase in enzyme activity over the control was found. Data was analyzed statistically in Table5. The enzyme activity increased with the increase in exogenous JA concentrations at all exposure periods in comparison with the control. Jasmonic acid at 0.5 , $10 \mu \mathrm{mol}$ concentration range induced significant average (23, 33.3 and $43.3 \%)$ and ( 80,86 and $86 \%)$ increases respectively, in PAL activity during elicitation time.

Table 5. Effect of jasmonic acid (JA) on the phenylalanine ammonia-lyase enzyme activity during different harvesting times in the melon cell suspension culture cultivated in MS1 medium.

\begin{tabular}{cccc}
\hline \multirow{2}{*}{ JA $(\mu \mathrm{mol})$} & \multicolumn{3}{c}{$\begin{array}{c}\text { Phenylalanine ammonia-lyase activity } \\
\left(\mu \mathrm{mol} \text { cinnamic } \mathrm{min}^{-1} \mathrm{gm}^{-1} \mathrm{fw}\right)\end{array}$} \\
\cline { 2 - 4 } & $24 \mathrm{~h}$ & $48 \mathrm{~h}$ & $72 \mathrm{~h}$ \\
\hline Control & $0.30 \pm 0.01 \mathrm{~d}$ & $0.30 \pm 0.02 \mathrm{c}$ & $0.3 \pm 0.01 \mathrm{c}$ \\
0.5 & $0.37 \pm 0.03 \mathrm{c}$ & $0.40 \pm 0.01 \mathrm{~b}$ & $0.43 \pm 0.01 \mathrm{~b}$ \\
5.0 & $0.41 \pm 0.01 \mathrm{~b}$ & $0.43 \pm 0.03 \mathrm{~b}$ & $0.47 \pm 0.04 \mathrm{~b}$ \\
10.0 & $0.54 \pm 0.01 \mathrm{a}$ & $0.56 \pm 0.04 \mathrm{a}$ & $0.56 \pm 0.04 \mathrm{a}$ \\
LSD at $5 \%$ & 0.033 & 0.052 & 0.055 \\
\hline
\end{tabular}

Values (means of three replicates $\pm \mathrm{SD}$ ) in the same column followed by the same letter are not significantly different at $p<0.05$.

The effect of JA on PPO activity was examined in melon cell suspension to evaluate its response after exogenous $\mathrm{JA}$ application. Under the influence of $0.5,5.0$ and $10 \mu \mathrm{mol} \mathrm{JA}$ changes in PPO enzyme activity compared to the control was recorded. Data was represented and analyzed statistically in Table 6. Melon cells elicited with JA at $0.5 \mu \mathrm{mol}$ significantly suppressed their PPO activity in average 70, 43.8 and $30.9 \%$ lower than the control in respect with post elicitation time. On the other hand, at 5 and $10 \mu \mathrm{mol} \mathrm{JA}$ significant increases were found (51.4, 25.8 and 24.3\%; and 54.2, 40.4 and 67.4\%, respectively) in melon cells during harvesting time interval. 
Table 6. Effect of jasmonic acid (JA) on polyphenol oxidase enzyme activity during different harvesting times in the melon cell suspension culture cultivated in MS1 medium.

\begin{tabular}{cccc}
\hline \multirow{2}{*}{ JA $(\mu \mathrm{mol})$} & \multicolumn{3}{c}{$\begin{array}{c}\text { Polyphenol oxidase activity } \\
\left(\Delta \mathrm{min}^{-1} \mathrm{gm}^{-1}\right)\end{array}$} \\
\cline { 2 - 4 } & $24 \mathrm{~h}$ & $48 \mathrm{~h}$ & $72 \mathrm{~h}$ \\
\hline Control & $1.44 \pm 0.04 \mathrm{c}$ & $1.78 \pm 0.09 \mathrm{c}$ & $1.81 \pm 0.08 \mathrm{c}$ \\
0.5 & $0.43 \pm 0.03 \mathrm{~b}$ & $1.00 \pm 0.03 \mathrm{~d}$ & $1.25 \pm 0.04 \mathrm{~d}$ \\
5.0 & $2.18 \pm 0.05 \mathrm{a}$ & $2.24 \pm 0.15 \mathrm{~b}$ & $2.25 \pm 0.18 \mathrm{~b}$ \\
10.0 & $2.22 \pm 0.06 \mathrm{a}$ & $2.50 \pm 0.19 \mathrm{a}$ & $3.03 \pm 0.19 \mathrm{a}$ \\
LSD at $5 \%$ & 0.087 & 0.244 & 0.260 \\
\hline
\end{tabular}

Values (means of three replicates \pm SD) in the same column followed by the same letter are not significantly different at $p<0.05$.

The induction of POX, PAL and PPO in elicited cells suggested that phenolics might be enhanced during elicitation. So changes in the profile of phenolic compounds extracted from melon cells and the medium in which they had been grown was investigated by gradient elution high performance liquid chromatography (GC-HPLC). After visual examination of the complete set of HPLC chromatograms, it was apparent that melon cell suspension was secreting several common and distinctive secondary metabolites under our experimental condition .Peaks were selected according to several criteria: the compounds displayed characteristic production within an 5-10 $\mu \mathrm{mol}$ elicitor treatment as well as the control; the compounds appeared on a specific harvest day(s), and concentration of the compounds which was enhanced compared to the other compounds secreted. We characterized 5 compounds on the basis of their potentials as elicitors of defense compounds previously described as endowed with this biological activity. The phenolics coumarin, caffeic, P-coumaric, salicylic and benzoic were identified in the cells and culture medium. Coumarin was the highest phenolic to increase concomitantly with JA elicitation in melon cells and the culture medium (Tables 7 and 8).

Table 7. Effect of jasmonic acid (JA) on the intracellular phenolic compounds production during different harvesting times in the melon cell suspension culture cultivated in MS1 medium. Values are expressed as $\mu \mathrm{g} / \mathrm{g}$ FW.

\begin{tabular}{|c|c|c|c|c|c|c|c|c|c|c|c|c|c|c|c|}
\hline \multirow{4}{*}{ JA } & \multicolumn{15}{|c|}{ Phenolic compounds $\mu \mathrm{g} \mathrm{g}^{-1} \mathrm{fw}$ (intracellular) } \\
\hline & \multicolumn{3}{|c|}{ Coumarin } & \multicolumn{3}{|c|}{ Caffeic acid } & \multicolumn{3}{|c|}{ P-coumaric acid } & \multicolumn{3}{|c|}{ Salicylic acid } & \multicolumn{3}{|c|}{ Benzoic acid } \\
\hline & \multicolumn{15}{|c|}{ Harvesting Time } \\
\hline & $24 \mathrm{~h}$ & $48 \mathrm{~h}$ & $72 \mathrm{~h}$ & $24 \mathrm{~h}$ & $48 \mathrm{~h}$ & $72 \mathrm{~h}$ & $24 \mathrm{~h}$ & $48 \mathrm{~h}$ & $72 \mathrm{~h}$ & $24 \mathrm{~h}$ & $48 \mathrm{~h}$ & $72 \mathrm{~h}$ & $24 \mathrm{~h}$ & $48 \mathrm{~h}$ & $72 \mathrm{~h}$ \\
\hline Control & 2.49 & 0.23 & - & 0.48 & 0.01 & - & 0.191 & - & - & 0.5 & 0.1 & - & 0.022 & - & - \\
\hline $5 \mu \mathrm{mol} \mathrm{JA}$ & 1.732 & 2.84 & 2.5 & 0.653 & 0.34 & 1.3 & 0.32 & 0.92 & 0.9 & - & - & - & - & - & - \\
\hline $10 \mu \mathrm{mol} \mathrm{JA}$ & 1.505 & 3.07 & 3 & 0.963 & 1.44 & 0.5 & 0.451 & 0.59 & 0.3 & - & 0 & - & - & - & - \\
\hline
\end{tabular}

In melon cells the changes were recorded in abundance of three of these phenolics (coumarin, caffeic and P-coumaric), and other compounds (salicylic and benzoic) generally disappeared under JA elicitation from the melon cells compared to the control (Table7). On the other hand while still there is great increase under elicitation between the control and the elicited medium in coumarin, caffeic, P-coumaric mean while salicylic and benzoic detected only in elicited and not detected in control medium (Table 8). At $10 \mu \mathrm{mol} \mathrm{JA}$ a remarkable accumulation in coumarin and p-coumaric was detected in melon cells as well as in the culture medium. 
Table 8. Effect of jasmonic acid $(\mathrm{JA})$ on the extracellular phenolic compounds production during different harvesting times in the melon cell suspension culture cultivated in MS1 medium. Values are expressed as $\mu \mathrm{g} / \mathrm{g}$ FW.

\begin{tabular}{|c|c|c|c|c|c|c|c|c|c|c|c|c|c|c|c|}
\hline \multirow{4}{*}{ JA } & \multicolumn{15}{|c|}{ Phenolic compounds $\mu \mathrm{g} \mathrm{g}^{-1} \mathrm{fw}$ (intracellular) } \\
\hline & \multicolumn{3}{|c|}{ Coumarin } & \multicolumn{3}{|c|}{ Caffeic acid } & \multicolumn{3}{|c|}{ P-coumaric acid } & \multicolumn{3}{|c|}{ Salicylic acid } & \multicolumn{3}{|c|}{ Benzoic acid } \\
\hline & \multicolumn{15}{|c|}{ Harvesting Time } \\
\hline & $24 \mathrm{~h}$ & $48 \mathrm{~h}$ & $72 \mathrm{~h}$ & $24 \mathrm{~h}$ & $48 \mathrm{~h}$ & $72 \mathrm{~h}$ & $24 \mathrm{~h}$ & $48 \mathrm{~h}$ & $72 \mathrm{~h}$ & $24 \mathrm{~h}$ & $48 \mathrm{~h}$ & $72 \mathrm{~h}$ & $24 \mathrm{~h}$ & $48 \mathrm{~h}$ & $72 \mathrm{~h}$ \\
\hline Control & - & 2.9 & - & 0.248 & 0.12 & - & 0.451 & 0.17 & - & - & - & - & - & - & - \\
\hline $5 \mu \mathrm{mol} \mathrm{JA}$ & - & 25.4 & 30 & - & - & 1 & 0.224 & 3.64 & 3.4 & - & 0.1 & 0.1 & - & - & - \\
\hline $10 \mu \mathrm{mol} J \mathrm{~A}$ & 19.64 & 3.7 & 26 & 0.424 & 0.72 & - & 2.77 & 0.77 & 3.8 & 0.056 & - & 0.1 & - & - & 0 \\
\hline
\end{tabular}

Changes in total flavonoids content: The effect of extracellular application of JA on the total flavonoids content in melon cell suspension culture is demonstrated in Figure 3. The data revealed that application of JA to melon culture medium enhanced melon total flavonoids. At low dose, melon treated cells significantly accumulate fairly low amount (5.5\%) after $24 \mathrm{~h}$, meanwhile the other two doses accumulate higher amounts in dose depend manner (49 and 58\%) compared to the control. Two days post elicitation exhibited different responses as compared to the first day, while $\mathrm{JA}$ at $0.5 \mu \mathrm{mol}$ significantly increased the flavonoids (30\%), at 5 and $10 \mu \mathrm{mol} \mathrm{JA}$ induced lower amounts $(33.3,36.2 \%)$ compared to the control. Going to the third day the highest JA concentration induced the highest amount $64 \%$ in melon culture compared to the control.

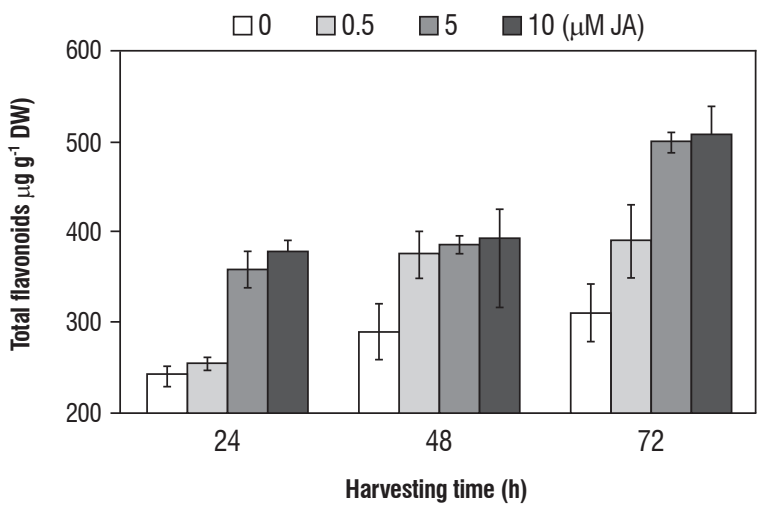

Figure 3. Effect of jasmonic acid (JA) on the total flavonoids production during different harvesting times in the melon cell suspension culture cultivated in MS1 medium.

\section{DISCUSSION}

Cell-suspension cultures are handled relatively easily, which make them valuable and attractive for standardized experiments to study elicitor-induced defense responses. For different cell-suspension cultures, a variety of elicitor molecules have been shown to induce defense-related responses that are similar to the responses in elicited plants. In the present study we found that elicitation could be a promising strategy to drive melon cells toward modulating specific secondary metabolites production concomitant with specific oxidative defense mechanisms. Exogenous JA application which lead to endogenous JA enhancement probably result from and activates JA signaling pathways and the related defense gene expression, without damaging the melon nucleic acids (Nafie et al., 2009), and also may be responsible for other cascades of biochemical and molecular events. Our results together with some previous studies on JA as influential integral elicitor, suggest that JA can potentiate melon cells defense responses via modulating ascorbic acid and phenolic metabolism, total flavonoids, coumarins and ROS -detoxification enzyme systems.

Antioxidant enzyme enhancement, a response related to ROS detoxification, was increased under diverse environmental stress situations (Mittler, 2002). Catalase, a detoxifying system member, converts $\mathrm{H}_{2} \mathrm{O}_{2}$ to form oxygen and water. Ali et al. (2005) found that CAT activity declined severely in Panax ginseng and Panax quinquefolium plants, under methyl jasmonate (MJ) stress, pointing to inactivation in CAT activity and isoenzymes expression. Also Chong et 
al. (2005) shows that CAT activity was lower in JA treated Morinda elliptica cell cultures after 6 days of elicitation. The suppression in CAT activity have similarly been reported in fungal-elicited Catharanthus roseus cell cultures (Zhao et al., 2001) and water-stressed in strawberry plants (Wang, 1999). In contrast, MJ treatment of strawberry plant increases CAT activity (Wang, 1999). In the present study, CAT in melon cells exposed to the highest JA concentrations cause significant increase in enzyme activity, probably to overcome the transient increase in $\mathrm{H}_{2} \mathrm{O}_{2}$ levels which require a prompt generation of ROS-scavenging systems to neutralize its adverse effects in cell membranes stability.

Peroxidases participate in a variety of defense mechanisms (Liu et al., 2008), to ameliorate oxidative burst a common event in defense response (Lamb and Dixon, 1997). In our work, induction of peroxidases (POD) in melon cells during the time course of elicitation, may result from enzyme activation and/or the de novo differential expression in POD isoforms, implicating them in stress alleviation, as POD expression is controlled by multiple genes (Gomez-vasquez et al., 2004). On the other hand, Bestwick et al. (1998); Martinez et al. (1998) and Zhao et al. (2001) found that apoplastic peroxidases have been responsible for the oxidative burst in an increasing list of plant species. Cell wall-bound POD enzyme activity in melon tissues treated with JA collaborates in $\mathrm{H}_{2} \mathrm{O}_{2}$ production, but it is not the major factor, but implicates it in cells membrane stability disturbance resulted in transient leakage of important compounds into growth media. Liu et al. (2008) found that cell wall POD activity in JA treated pea leaves were not parallel to the $\mathrm{H}_{2} \mathrm{O}_{2}$ accumulation which is in line with our data. In the present work, assessing exogenous $\mathrm{JA}$ application on ascorbic acid metabolism revealed that JA modulates its content. Plants synthesize ascorbic acid via de novo synthesis and salvage pathways, but the regulation of its biosynthesis and the mechanisms behind ascorbate homeostasis are largely unknown (Valpuesta and Botella, 2004). Jasmonic acid and its methyl ester (jasmonates) mediate plant responses to many biotic and abiotic stresses by triggering a transcriptional reprogramming that allows cells to cope with these stress. In this regard, Wolucka et al. (2005) proposed that, in tobacco BY-2 cells, MJ stimulated the de novo biosynthesis of L-ascorbic acid, at least in part, by enhanced transcription of MJ-responsive genes encoding key enzymes of vitamin C synthesis. Also they found that, in Arabidopsis cell suspension phytohormones (auxin and/ or cytokinin) not only are necessary to support growth but also affect jasmonates-elicited L-AA synthesis, but such relationship is not understood. In our results, MS1 (MS medium supplemented with $2 \mathrm{mg}^{-1} \mathrm{~L}$ 2, 4-D; $0.1 \mathrm{mg}^{-1} \mathrm{~L}$ BA and $30 \mathrm{~g}^{-1} \mathrm{~L}$ sucrose) medium the hormonal composition seems crosstalk with JA signaling pathways, including AA genes enhancement.

It was found an AA imbalance between melon cells and its growth medium, where the highest level in the elicited growth medium was recorded after only one day compared to control, resulting in membrane efficient permeability under transient hydrogen peroxide production. Estimated AA levels undergoing the JA control as stated previously to affect directly genes for AA biosynthesis.

Ascorbate peroxidase is a key hydrogen peroxide scavenging enzyme and its isoforms are present in different cell compartments (Jimenez et al., 1997). In plant cells, APX expression is induced in response to many environmental stresses that result in the accumulation of ROS (Karpinski et al., 1999; Mittler, 2002). In particular, methyl jasmonate stimulated APX expression at the levels of mRNA (Orvar et al., 1997), protein (Rakwal et al., 1999) and enzyme activity (Maksymiec and Krupa, 2002). In contrast, Chong et al. (2005) showed that ascorbic peroxidase activity was lower in JA elicited Morinda elliptica cells than in control. In our work and during 24h, transient increase in $\mathrm{H}_{2} \mathrm{O}_{2}$ concomitant with AA availability stimulating APX activity to counter balance hydrogen peroxide impact and thus preventing the cell membrane permeability.

Significant increase in glutathione reductase (GR) enzyme activity in JA treated melon cells should play a crucial role in protecting the tissues against oxidative stress by maintaining the GSH level so antagonizing the consumption of AA and recycling it for APX and ascorbic oxidase (AO) as well as to maintain AA level for its crucial role as antioxidant metabolite.

Fotopoulos et al. (2006) reported that lowering the apoplast $\mathrm{AA}$ redox state, through increased $\mathrm{AO}$ expression in transgenic tobacco (Nicotiana tabacum L. cv. Xanthi), exerts no effects on the expression levels of genes involved in AA recycling under normal growth conditions, but plants display enhanced sensitivity to various oxidative stress-promoting agents. Ascorbate oxidase expression is modulated by 
complex transcriptional and translational controls (Esaka et al., 1992). Kato and Esaka (2000), found that the activity and expression of $\mathrm{AO}$ are closely correlated with cell expansion and Pignocchi et al. (2003) stated that the enzyme transcript levels increased upon growth promoters exposure, such as auxin and jasmonates (Sanmartin, 2002).

Perturbation in ascorbic acid oxidase (A0) activity in treated melon cells was evaluated and the resulted data imply that 5 and $10 \mu \mathrm{mol} \mathrm{JA}$ enhanced the enzyme activity, while JA at $0.5 \mu \mathrm{mol}$ inhibited this enzyme. Increase in enzyme activity may compromise the tissue detoxification potential ability and JA may be implicated in activating AA-recycling genes to protect cells from membrane damage.

Elicitation of in vitro cultures is a useful approach to enhance and extend production of desirable products (OksmanCaldentey and Inze, 2004). Elicitors are now considered as signal molecules that activate the signal-transduction cascade which lead to the activation and expression of genes related to the biosynthesis of secondary metabolites (Zhao et al., 2005). Wang and Wu (2005) stated that MJ, is an effective inducer of the secondary metabolite diterpenoid taxol (paclitaxel) in Taxus spp. and that exogenously supplied MJ at $100 \mu$ mol induced rapid production of $\mathrm{NO}$ concomitantly with the phenylalanine ammonia-lyase (PAL) activation. Liu et al. (2008) found that $10 \mu \mathrm{mol}$ JA treatment of pea leaves (Pisum sativum), led to a significant increase in activities of plasma membrane NADPH oxidase and PAL. Jasmonates elicitation was also found to increase the production of phenylpropanoids and naphtodianthrones in Hypericum perforatum cell suspensions (Gadzovska et al., 2007).

Secondary metabolite production is usually associated with rapid, transient increases in activities of key enzymes of the phenylpropanoid / flavonoid pathway such as PAL and chalcone isomerase (Gundlach et al., 1992; Dixon et al., 2002). In addition, many studies have shown that polyphenol oxidase (PPO) is induced in response to mechanical wounding, fungal and bacterial infection, and by treatment with signaling molecules, such as JA /MJ and salicylic acid (Constabel et al., 2000; Stewart et al., 2001). Defense proteins whose expression is dependent on the $\mathrm{JA} / \mathrm{CO} 1$ pathway include polyphenol oxidase (Browse and Howe, 2008).

In JA-treated melon cells PAL and PPO enzymes and total flavonoid were significantly enhanced. As PAL controls the initial step in the phenolic compounds biosynthesis pathway, factors induced enzyme activity will encourage phenolic compound enrichment. Also the present results indicate the presence of coumarin and four phenolic acids: caffeic, p-coumaric, salicylic and benzoic to different levels in both JA-elicited melon cells and in the MS1 growth medium with respect to the control.

Increase in the caffeic and p-coumaric acids was recorded in melon cells and growth medium, which was still detectable three days after JA-elicitation. These results agree with those reported by Kauss et al. (1992a) who found in the dark-grown parsley culture that MJ-treatment at 1 to 5 $\mu \mathrm{mol}$ results in a synergistic increase in coumarin secretion and incorporation of phenolics into the cell walls. Zulak et al. (2008) studying opium poppy (Papaver somniferum) have found that coumarate levels initially increased in elicitortreated cells more rapidly than in controls, but subsequently decreased from $50-80 \mathrm{~h}$ in both cases. Benzoic acid (BA) and its derivatives also play important roles in biotic and abiotic stress responses and are incorporated into several secondary defense-related metabolites (Wildermuth, 2006). Present data analysis revealed that BA and salicylic acid (SA) were not involved in the melon responses to the JA-elicitation since they were undetectable in both the elicited melon cells and growth medium. But worthy note is that SA was recorded but only in the non elicited melon cells during the $48 \mathrm{~h}$ and then disappeared. In contrast, in Arabidopsis, leaves challenged with various biotic and abiotic stresses, methylbenzoate was found to be induced (Chen et al., 2003) and benzoic carboxymethyl-transferases were also induced under similar conditions (Effmert et al., 2005). On the other hand, Zulak et al. (2008) stated that BA have not yet been identified in opium poppy (Papaver somniferum) as a key component of functional genomics platform during investigating the interplay between primary and secondary metabolism in cultured opium poppy cells treated with a fungal elicitor.

Flavonoids are a large group of stress-induced phenylpropanoids that possess antioxidant activity and play an important role in antimicrobial defense, protection against high light and oxidative stress, and signaling. The biosynthesis of flavonoids involves four closely related enzymes which are (Martens et al., 2003) ascorbate-dependent and reported to be under the JA control (Wolucka et al., 2005). In the present work, significant increase obtained in total flavonoids may be 
modulated and controlled by the AA availability, which had been induced and its synthesis was shown previously to be reprogrammed by JA in melon cells.

Acknowledgements: Authors greatly appreciate technical cooperation with Gene Transfer Lab (GTL), Agricultural Genetic Engineering Research Institute (AGERI), Agricultural Research Centre (ARC), Cairo, Egypt.

\section{REFERENCES}

Aebi $\mathrm{H}$ (1984) Catalase in vitro. Methods in Enzymology. 105:121-126.

Ali MB,Yu KW, Hahn EJ, Paek KY (2005) Differential responses of anti-oxidants enzymes, lipoxygenase activity, ascorbate content and the production of saponins in tissue cultured root of mountain panax ginseng C.A. Mayer and Panax quinquefolium $\mathrm{L}$. in bioreactor subjected to methyl jasmonate stress. Plant Sci. 169: 83-92.

Asada K (1999) The water-water cycle in chloroplasts: scavenging of active oxygen and dissipation of excess photons. Annul. Rev. Plant Physiol. Plant Mol. Biol. 50: 601-639.

Barnes JD, Zheng Y, Lyons TM (2002) Plant resistance to ozone: the role of ascorbate. In: Omasa K, Saji H, YousseWan S, Kondo N (eds) Air pollution and plant biotechnology, Springer, Berlin Heidelberg New York, pp 235-252.

Bestwick SC, Brown IR, Mansfield JW (1998) Localized changes in peroxidase activity accompanies hydrogen peroxide generation during the development of a nonhost hypersensitive reaction in lettuce. Plant Physiol. 118: $1067-1078$

Browse J, Howe GA (2008) New weapons and a rapid response against insect attack. Plant Physiol. 146: 832-838.

Buschmann H, Rodriguez, MX, Tohme J, Beeching JR (2000) Accumulation of hydroxycoumarins during post-harvest deterioration of tuberous roots of cassava (Manihot esculenta Crantz).Ann Bot 86: 1153-1160.

Chen F, D'Auria JC, Tholl D, Ross JR, Gershenzon J, Noel JP, Pichersky E ( 2003) An Arabidopsis thaliana gene for methylsalicylate biosynthesis, identified by a biochemical genomics approach, has a role in defense. Plant J. 36:577-588.

Chong TM , Abdullahd MA, Fadzillahb NM, Laia OM, Lajisc NH (2005) Jasmonic acid elicitation of anthraquinones with some associated enzymic and non-enzymic antioxidant responses in Morinda elliptica. Enzyme MicrobTechnol. 36: 469-477.

Constabel CP,Yip L, Patton JJ, Christopher ME (2000) Polyphenol oxidase from hybrid poplar, cloning and expression in response to wounding and herbivore. Plant Physiol. 124: 285-95.

Dickerson DP, Pascholati SF, Hagerman AE, Butler LG, Nichol son RL (1984) Phenylalanine ammonia-lyase and hydroxycinnamate: CoA ligase in maize mesocotyls inoculated with Helminthosporium maydis or Helminthosporium carbonum. Physiol. Plant Pathol. 25: 111-123.

Dixon RA, Ferreira D, Genistein S (2002) The phenylpropanoid pathway and plant defense - a genomics perspective. Mol. Plant Pathol. 3: 371-390.

Effmert U, Saschenbrecker S, Ross J, Negre F, Fraser CM, Noel JP, Dudareva $\mathrm{N}$, Piechulla B (2005) Floral benzenoid carboxyl methyltransferases: from in vitro to in planta function. Phitochem. 66:1211-1230.

Esaka M, Fujisawa K, Goto M, Kisu Y (1992) Regulation of ascorbate oxidase expression in pumpkin by auxin and copper. Plant Physiol. 100: 231-237.

Esaka M, Uchida M, Fukui H, Kubota K, Suzuki K (1988) Marked increase in ascorbate oxidase protein in pumpkin callus by adding copper. Plant Physiol. 88: $656-660$.
Fotopoulos v, Sanmartin M, Kanellis AK (2006) Effect of ascorbate oxidase over-expression on ascorbate recycling gene expression in response to agents imposing oxidative stress. J Exp Bot. 1-11

Gadzovska S, Maury S, Delaunay A, Spasenoski M, Joseph C, Hagege D (2007) Jasmonic acid elicitation of Hypericum perforatum L. cell suspensions and effects on the production of phenylpropanoids and naphtodianthrones. Plant Cell Tiss. Organ Cult. 89:1-13.

Gomez-Vasquez R, Day R, Buschmann H, Randles S, Beeching JR, Cooper RM (2004) Phenylpropanoids, phenylalanine ammonia-lyase and peroxidases in elicitor-challenged Cassava (Manihot esculenta) suspension cells and leaves. Ann. Bot. 94: 8797.

Gundlach H, Muller M J, Kutchan M, Zenk M H (1992) JA is a signal transducer elicitor-induced plant cell cultures. Proc Nat Acad Sci USA. 89:2389-2393.

Haider NB, Jacobson SG, Cidecyan AV, Swiderski R, Streb LM, Searby C, Beck G, Hockey R, Hanna DB, Gorman S (2000) Mutation of a nuclear receptor gene, nr2e3, causes enhanced cone syndrome, a disorder of retinal cell fate. Nat. Genet. 24: 127-31.

Hodges D, Andrews C, Johnson DA, Hamilton RI (1997) Antioxidant enzyme responses to chilling stress in differentially sensitive inbred maize lines. J. Exp. Bot. 48: 1105-13.

Jagota SK, Dani HM (1982) A new colorimetric technique for the estimation of vitamin C using Folin phenol reagent. Anal. Biochem. 127: 178-182.

Jiang AL, Tian SP, Xu Y (1984) Effect of controlled atmospheres with high $\mathrm{O}_{2}$ or high- $\mathrm{CO}_{2}$ concentrations on postharvest physiology and storability of "Napoleon" sweet cherry. J. Integrative Plant Biol. 44: 925-930.

Jiang M, Zhang J (2002) Water stress-induced abscisic acid accumulation triggers the increased generation of reactive oxygen species and up-regulates the activities of antioxidant enzymes in maize leaves. J Exp Bot 53(379): 2401-2410.

Jimenez A, Hernandez JA, Del Rio LA, Sevilla F (1997) Evidence for the presence of the ascorbate-glutathione cycle in mitochondria and peroxisomes of pea leaves. Plant Physiol. 114: 275-284.

Karpinski S, Reynolds H, Karpinska B, Wingsle G, Creissen G, Mullineaux P (1999) Systemic signalling and acclimation in response to excess excitation energy in Arabidopsis. Science. 284: 654-657.

Kato N, Esaka M (2000) Expansion of transgenic tobacco protoplasts expressing pumpkin ascorbate oxidase is more rapid than that of wild-type protoplasts. Planta. 210: 1018-1022.

Kauss, H, Krause, K, Jeblick, W (1992a) Methyl jasmonate conditions parsley suspension cells for increased elicitation of phenyl propanoid defense responses. Biochem. Biophys. Res. Commun. 189: 304-308.

Kiddle G, Pastori GM, Bernard S, Pignocchi C, Antoniw J, Verrier PJ, Foyer CH (2003) Effects of leaf ascorbate content on defense and photosynthesis gene expression in Arabidopsis thaliana. Antiox Redox Signal. 5: 3-32.

Knight H , Knight MR (2001) Abiotic stress signaling pathways: specificity and cross-talk. Trends Plant Sci. 6: 262-267.

Lamb C, Dixon RA (1997) The oxidative burst in plant disease resistance. Annul. Rev. Plant Physiol Plant Mol. Biol. 48:251-75.

Lee HS, Wicker L (1991) Anthocyanin pigments in the skin of lychee fruit. J Food Sci. 6(2): 466-468, 483.

Liu Y,Pan QH, Yang HR, Liu YY, Huang WD (2008) Relationship between $\mathrm{H}_{2} \mathrm{O}_{2}$ and Jasmonic acid in Pea leaf wounding response. Russ $\mathrm{J}$ Plant Physiol. 55(6): 851-862.

Luh BS, Phithakpol B (1972) Characteristics of polyphenol oxidase related to browning in cling peaches. J. Food Sci. 37: 264-268.

Maksymiec W, Krupa Z (2002) The in vivo and in vitro influence of methyl jasmonate on oxidative processes in Arabidopsis thaliana leaves. Acta Physiol Plantarum. 24: 351-357. 
Martens S, Knott J, Seitz CA, Janvari L (2003) Impact of biochemical pre studies on specific metabolic engineering strategies of flavonoid biosynthesis in plant tissues. Biochem. Eng. J. 14: 227-235.

Martinez C, Montillet JL, Bresson E, Agnel JP, Dai GH, Daniel JF, Geiger JP, Nicole M (1998) Apoplastic peroxidase generates superoxide anions in cells of cotton cotyledons undergoing the hypersensitive reaction to Xanthomonas campestris pv malvacearum. Race 18, Mol. Plant-Microbe Int. 11: 10381047.

Martyn RD, Miller ME (1996) Monosporascus root rot/vine decline: An emerging disease of Melons worldwide. Plant Dis. 80: 716-725

Nafie E, Hussein G, Al Mokadem AIS (2009) Jasmonic acid elicitation modulates anthraquinones production and evokes defense responses in Cucumis melo L. cell suspension culture. African J. Biol. Sci. 5(2): 63-96.

Naill MC, Roberts SC (2005) Cell cycle analysis of Taxus suspension cultures at the single cell level as an indicator of culture heterogeneity. Biotechnol. Bioeng. 90: 491-500.

Nakano Y, Asada K (1981) Hydrogen peroxide is scavenged by ascorbatespecific peroxidase in spinach chloroplasts. Plant Cell Physiol .22: 867-880.

Noctor G, Foyer C (1998) Ascorbate and glutathione: keeping active oxygen under control. Annul. Rev. Plant Physiol. Plant Mol. Biol. 49: 249-279

Oberbacher MF, Vines HM (1963) Spectrophotometric assay of ascorbic acid oxidase. Nature. 197:1203-1204.

Oksman-Caldentey KM, Inze' D (2004) Plant cell factories in the postgenomic era: new ways to produce designer secondary metabolites. Trends Plant Sci. 9: 433-440.

Orvar BL, McPherson J, Ellis BE (1997) Pre-activating wounding response in tobacco prior to high-level ozone exposure prevents necrotic injury. Plant J. 11: 203-212.

Pastori GM, Foyer CH (2002) Common components, networks, and pathways of cross-tolerance to stress. The central role of 'redox' and abscisic acidmediated controls. Plant Physiol. 129: 460-468.

Pignocchi C, Fletcher J, Barnes J, Foyer CH (2003) The function of ascorbate oxidase (A0) in tobacco (Nicotiana tabacum L.). Plant Physiol. 132: 16311641.

Pignocchi C, Foyer CH (2003) Apoplastic ascorbate metabolism and its role in the regulation of cell signaling. Curr Opin Plant Biol. 6: 379-389.

Potters G, Horemans N, Bellone S, Caubergs J, Trost P, Guisez Y, Asard H (2004) Dehydroascorbate influences the plant cell cycle through a glutathione independent reduction mechanism. Plant Physiol. 134:1479-1487.

Rakwal R, Agrawal GK, Yonekura M (1999) Separation of proteins from stressed rice (Oryza sativa L.) leaf tissues by two dimensional polyacrylamide gel electrophoresis: induction of pathogenesis-related and cellular protecting proteins by jasmonic acid, UV irradiation and copper chloride. Electrophoresis. 20: 3472-3478.

Ranieri A, Nali G, D'Urso G (1995) Peroxidase activity in Cucurbita pepo L. leaves exposed to ozone. Agricoltura Mediterranea. (Special volume) 47-54.

Richter H (2000) Fresh produce guide: Nutrition, selection, preparation, storage, handling, cooking. Try-Foods Intl. Inc. Apopka, FL.

Mittler R (2002) Oxidative stress, antioxidants and stress tolerance. Trends Plant Sci . 7 : 405-410.

Sanmartin M (2002) Regulation of melon ascorbate oxidase gene expression and effect of its modification in transgenic tobacco and melon plants.Spain ,University of Valencia .Ph.D. thesis.
Smirnoff N (2000) Ascorbic acid: metabolism and functions of a multifacetted molecule. Curr. Opin. Plant Biol. 3:229-235.

Stewart RJ, Sawyeer BJB, Bucheli CS, Robinson SP(2001) Polyphenol oxidase is induced by chilling and wounding in pineapple. Aust. J. Plant Physiol. 28:181-191.

Tokunaga T, Miyahara K, Tabata K, Esaka M (2005) Generation and properties of ascorbic acid-overproducing transgenic tobacco cells expressing sense RNA for L-galactono-1,4-lactone dehydrogenase. Planta. 220: 854-863.

Valpuesta V, Botella MA (2004) Biosynthesis of L-ascorbic acid in plants: new pathways for an old antioxidant. Trends Plant Sci. 9: 573-577.

Vranova E, Inze D, Breusegem FV (2002) Signal transduction during oxidative stress. J. Exp. Bot. 53: 1227-1236.

Wang JW, Wu JY (2005) Nitric oxide is involved in methyl jasmonate-induced defense responses and secondary metabolism activities of Taxus cells. Plant Cell Physiol. 46(6): 923-30.

Wang SY (1999) Methyl jasmonate reduces water stress in strawberry. Plant Growth Regul. 18: 127-34.

Wang W, Zhao ZJ, Xu Y F, Qian XH, Zhong JJ (2005) Efficient induction of ginsenoside biosynthesis and alteration of ginsenoside heterogeneity in cell cultures of Panax notoginseng by using chemically synthesized 2-hydroxyethyl jasmonate. Appl. Microbiol. Biotechnol. 70: 298-307.

Wildermuth MC (2006) Variations on a theme: synthesis and modification of plant benzoic acids. Curr. Opin. Plant Biol. 9: 288-296

Wolucka BA, Goossens A, Inze 'D (2005) Methyl jasmonate stimulates the de novo biosynthesis of vitamin $C$ in plant cell suspensions. J Exp Bot. 56(419): 2527-2538

Yadav RC, Salah MT, Grume R (1996) High frequency shoots regeneration from leaf explant of muskmelon. Plant Cell Tiss Organ Cult. 45: 207-214.

Yamunarani $K$, Jaganathan R, Bhaskaran R, Govindaraju P, Velazhahan $R$ (2004) Induction of early blight resistance in tomato by Quercus infectoria gall extract in association with accumulation of phenolics and defense-related enzymes. Acta Physiol Plantarum. 26(3): 281-290

Yingsanga P, Srilaong V, Kanlayanarat S, Noichinda S, McGlasson WB (2008) Relationship between browning and related enzymes (PAL, PPO and POD) in rambutan fruit (Nephelium lappaceum Linn.) cvs. Rongrien and SeeChompoo. Postharvest Biol Technol. 50: 164-168.

Yong SP, Soon TJ, Seong GK, Buk GH, Patricia AA, Fernando T (2008) Antioxidants and proteins in ethylene-treated kiwi fruits. Food Chem.107 (2): 640-648.

Zhao J, Davis LC, Verpoorte R (2005) Elicitor signal transduction leading to production of plant secondary metabolites. Biotechnol. Adv. 23: 283-333.

Zhao J, Hu Q, Guo YQ, Zhu WH (2001) Elicitor-induced indole alkaloid biosynthesis in Catharanthus roseus cell cultures is related to $\mathrm{Ca}^{2+}$ influx and the oxidative burst. Plant Sci. 161:423-31.

Zulak KG, Weljie AM, Vogel HJ, Facchini PJ (2008) Quantitative 1H NMR metabolomics reveals extensive metabolic reprogramming of primary and secondary metabolism in elicitor-treated opium poppy cell cultures. BMC Plant Biology. 8: 5 